\title{
Flatfish Pathogens in Marine Aquaculture and Their Importance in Medicine
}

\author{
Viroj Wiwanitkit ${ }^{*}$, Joseph ${ }^{2}$, Patil, DY ${ }^{3}$ \\ ${ }^{1}$ Department of Medicine, Hainan Medical University, Thailand \\ ${ }^{2}$ Deparment of Medicine, Ayobabalola University, Nigeria \\ ${ }^{3}$ Department of Medicine, Surin Rajabhat University, Thailand
}

*Corresponding Author: Viroj Wiwanitkit, Department of Medicine, Hainan Medical University, Thailand; E-mail: wviroj@ yahoo.com

Citation: Wiwanitkit, V., et al. Flatfish Pathogens in Marine Aquaculture and Their Importance in Medicine. (2015) J Marine Biol Aquacult 1(2): 30 .

\section{Introduction}

An important concern in aquaculture is the pathogen causing infections. For the flatfish aquaculture, the two important pathogens are Tenacibaculum maritimum and Edwardsiella tarda ${ }^{[1]}$. The pathogens can be the problem to the fishes. In addition, the problem to human being should also be discussed. Focusing on the two pathogens, there are some reports on human infected cases, especially those caused by Edwardsiella tarda. Edwardsiella tarda can cause the gastrointestinal infection in human beings. For Edwardsiella tarda, it is also reported as a cause of human infected hepatic cyst $\mathrm{t}^{[2,3]}$. It is also reported as a pathogen causing infection in a case with relapse of ulcerative colitits ${ }^{[4]}$. Kadam concluded that "A bacterium associated with fresh water ecosystems, can cause life-threatening illnesses in susceptible hosts ${ }^{[5]}$." Gauthier noted that "some epidemiological and/or molecular linkages have been made between other bacteria infecting both fishes and humans, but more work is needed to elucidate routes of transmission and the identity of these pathogens in their respective hosts at the genomic level ${ }^{[6]}$." Based on the existed evidence, disease from flatfish to human beings during aquaculture as a new emerging zoonosis must be a new interdisciplinary issue for future research ${ }^{[7]}$.

\section{References}

1. Castro, N., Toranzo, A.E., Magariños, B. A multiplex PCR for the simultaneous detection of Tenacibaculum maritimum and Edwardsiellatarda in aquaculture. (2014) Int Microbiol 17(2): 111-117.

2. Taguchi, H., Tamai, T., Numata, M., et al. Endoscopic ultrasonography-guided transmural drainage of an infected hepatic cyst due to Edwardsiella tarda: a case report. (2014) Clin J Gastroenterol 7(5): 422-428.

3. Ota, T., Nakano, Y., Nishi, M., et al. A case of liver abscess caused by Edwardsiella tarda. (2011) Intern Med 50(13): $1439-1442$. 4. Koido, S., Ohkusa, T., Kato, K., et al. Edwardsiella tarda superinfection in relapse of ulcerative colitis. (2014) J Clin Gastroenterol 48(2): 191-193.

5. Kadam, S.D. Edwardsiella tarda--a case report. (2013) Indian J Pediatr 80(1): 63-64.

6. Gauthier, D.T. Bacterial zoonoses of fishes: a review and appraisal of evidence for linkages between fish and human infections. (2015) Vet J 203(1): 27-35.

7. Kapel, C.M., Fredensborg, B.L. Foodborne parasites from wildlife: how wild are they? (2015) Trends Parasitol 31(4): 125-127. 